\title{
Lethal omphalocele-cleft palate syndrome
}

INSERM

\section{Source}

INSERM. (1999). Orphanet: an online rare disease and orphan drug data base. Lethal omphalocele-cleft palate syndrome. ORPHA:2736

Lethal omphalocele-cleft palate syndrome is characterized by the association of omphalocele and cleft palate. It has been described in three daughters of normal unrelated parents. They were all diag nosed at birth. One had omphalocele, posterior cleft palate, and uterus bicornuatus; she died at 2 months. The second had omphalocele, cleft uvula, and hydrocephalus and died at 4 months; the third had omphalocele and cleft palate and died at 1 year. This syndrome is likely to be inherited as an autosomal recessive condition. 